\title{
LOCAL VALUES AS A CONFLICT MEDIATION MODEL
}

\author{
Lahmuddin Zuhri, Syaifuddin Iskandar ${ }^{* *}$, Juanda $^{* * *}$, I Made Gusti \\ Sulindra ${ }^{* * * * *} \&$ Endra Syaifuddin
}

This study aims to describe the agrarian case in Sumbawa. Sumbawaness sees the land is the grace of trust which maintained and guarded through local values. Local value is the form of mediation model to solve agrarian cases. Besides that, this article uses legal anthropological that involves culture and gives an explanation of empirical and legal order in the structure of society. Mediation model is the the wisdom of local values. The principle is to involve all interested parties to participate in public space (life), so that loyalty and obedience to the community on what mutually agree upon will keep well together. As the agreement is the great of their thoughts and opinions together in shades of kinship and mutual glorify. Thus, local value expects to maintain the unity of the round and intact between mankind, nature, and God.

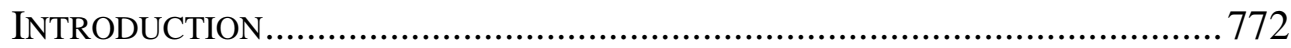

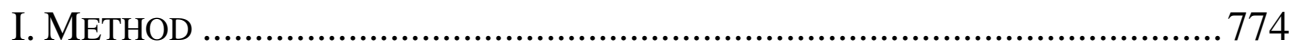

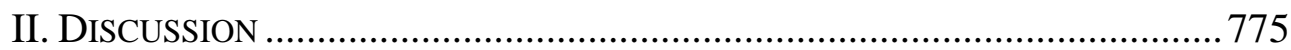

III. LOCAL VALUES AND SOCIETY SYSTEM ……........................................... 775

IV. LOCAL VALUE IN AGRARIAN CONFLICT................................................ 777

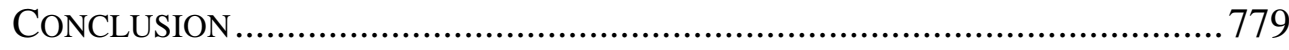

\section{INTRODUCTION}

Using local mediation model is already widely studied by researchers. Local is used as a mediation in a grarian cases. Mediation is not something outside to the life of society, including indigenous people with a variety. It is part of the social norms of living in life. This condition traces to the fact that tends to balance and harmony.

\footnotetext{
* Faculty of Law, Universitas Samawa, Indonesia. Research field: Legal Anthropological.

** Universitas Samawa, Member of APTISI, Indonesia. Research field: Sociology and Education.

*** Indonesian Language Education and Literature Department, Universitas Samawa, Indonesia.

Research fields: Indonesian Language Education, Indonesian Literature, and Indonesian Language Policy.

**** Education Technology Department, Universitas Samawa, Indonesia. Research fields: Education Assessment, Consulting and Counselling.

***** Law Department, Universitas Samawa, Indonesia. Research field: Criminal Law.
} 
Balance and harmony erode as the modernization ${ }^{1}$. One of the alternative conflict resolution is things that the concrete nature of customary law. It is very attentive to many problems. Thus, local values increase with humanity principles, such as: harmonious, inappropriate, and barrel. ${ }^{2}$ Customary law maintains an atmosphere where many conflicts resolution gain that address all aspects in the future. The mediation model needs to disclose agrarian cases.

In Indonesia, this study often knows as alternative conflict resolution. It is associated with politics and the legal experts who want to actualize the various institutions or living values in the community to address the social problems and agrarian cases. Deliberations to reach a conclusion about the conflict resolution process and decision making are considered to root in the various communities ${ }^{3}$, besides deliberation there are other ways commonly used by the public in resolving problems or conflicts, Indonesian given legal form through Rule No. 30/1999 on Arbitration and Alternative Conflict Resolution, namely: (1) coercion (violence) as a unilateral action by relying on physical force and violence, such as take legal action or inter-tribal warfare; (2) negotiation, means that there are two main groups which parties have agreement; (3) mediation, involves the intervention of a third party in the conflict to shore up the principles in reaching agreement.

Mediation as a form of alternative conflict resolution is not something strange, because it is part of the social norms of life. This condition could trace to the fact that people's lives are more oriented to balance and harmony. There were things that should not be forgotten, namely to always pay attention to the concrete nature of the local values. This means that local values are very attentiveness to many problems. Furthermore, it is explained that every matter should receive special treatment in accordance with individuality.

Local values are usually used in great number of tribes problem. For example, customary law of Banjar (South Borneo), law of Dayak (Central Borneo), law of village (Aceh Darussalam), and law of Kei (Southeast

\footnotetext{
${ }^{1}$ Maria S. W. Sumardjono, Nurhasan Ismail \& Isharyanto, Mediasi Sengketa Tanah, Potensi Penerapan Alternatif Penyelesaian Sengketa di Bidang Pertanahan (Mediation AND Resolution AgRARIAN CONFLICT IN AGRARIAN) (Jakarta: Kompas Press 2008).

${ }^{2}$ Moh Koesnoe, Hukum Adat Sebagai Suatu Model Hukum (Customary Law as Legal Model), (Bandung: Mandar Maju Press 1992).

${ }^{3}$ HadimUlyo, Mempertimbangkan ADR: Kajian Alternatif Penyelesaian Sengketa di Luar Pengadilan (To CONSIDERING OF ADR: RESOLUTION CONFLICT STUDIES IN JUDICIARY INSTITUTION) (Jakarta: LSAM and Social Advocacy Institute 1997).
} 
Moluccas) ${ }^{4}$. These are indigenous communities who implement a conflictre solution mechanism, as follows:

- Customary law of Banjar (South Borneo) is indigenous badamai (peaceful). This is one of the common forms of conflict resolution by Banjar".

- Customary law of Dayak (Central Borneo) is the principle of kinships, where the parties (perpetrator and victim) always strive to resolve their own problems peacefully.

- Customary law of Gampong (Aceh Darussalam) has separately settlement patterns, both vertical and horizontal conflicts. This is called gam.

- Customary law of Kei (South Moluccas) is Larvul Ngabal. Literally, Larvul means red blood, while Ngabal is speard from Bali.

\section{METHOD}

This study focuses to review the role of local values in the settlement of agrarian cases and to design model which uses to solve the problems. This research is a legal anthropological of local values in Sumbawa, West Nusa Tenggara, Indonesia. The legal anthropological is based on the fact that Indonesian people have multicultural diversity in nation state ${ }^{6}$. It wants to see the law is not an intellectual concept, but it is an institutional interactional.

Society is the general idea that signifies all social relationships, families, villages, social agencies, states, nations, economic systems, etc. Legal anthropology may provide an explanation of empirical data by analyzing the relationships of facts ${ }^{7}$.

Eventually, it can be seen legal institutions in the structure of society, so the activities of legal anthropology can be integrated with science of customary law dogmatic-normative. Then rule of law is always taken from the social facts that keep in people's confidence association ${ }^{8}$. So, enforcement is not necessary, even though to protect people.

\footnotetext{
${ }^{4}$ Ahmad Syaufi, Mediasi Penal sebagai Alternatif Penyelesaian Perkara Pidana Berasfek Berikatan (Penal Mediation as Resolution Case) (Malang: Brawijaya University Press 1997).

${ }^{5}$ AFFANI DAUd, Islam dan Masyarakat Banjar: Analisa Kebudayaan Banjar (IsLAM AND BANJAR SOCIETY: BANJAR CUltuRAL STUdieS) (Jakarta: Raja Grafindo Persada Press 1997).

${ }^{6}$ Budiono Kosumohamidjoyo, Kebinekaan Masyarakat Indonesia:Suatu Problematika Filsafat Kebudayaan (INDONESIAN Diversity: CUltURAL Philosophy) (Jakarta: Grasindo Press 2000). ${ }^{7}$ Valerina Jaqualine LeONORE KRIEKHOFF, Kedudukan Tanah Dati sebagai Tanah Adat di Maluku Tengah: Suatu Kajuan dengan Memanfaatkan Pendekatan Antropologi Hukum (DATI AGRARIAN IN MidDle MolUCCAS: ANTHROPOLOGY LAW STUDIES) (University of Indonesia: UI Press 1991).

${ }^{8}$ Lawrence M. Friendmann, The Legal System: A Social Sciance Perspective, translated by M. Khozim (Bandung: Nusa Media Press 2000).
} 


\section{DISCUSSION}

Local values are able to pay attention to many problems that confronted specifically and holistically. This model needs to disclose by considering conflicts area in society. Besides that, the authorities deny local values then they choose a litigation which brings consequences emergence of hostility because there are many elements wins-lose are packed to get justice. The assignment of legal science is to break the tension constantly. It is still between implementation and legislation, then to produce regulation as an agent of social developments'.

A living law is the law that lives in society. It includes the law emerged from the prevailing habits and formed to social interactions which involve a number of society. Local values feel peaceful conflicts resolution deliver to harmony, tolerance, balanced, protect togetherness in society. Indeed, Sumbawaness is familiar with a variety of changes, including agrarian conflicts in society. Legal anthropology and pluralism dismantled the hegemony and the law state centralism, such as the aims of this study to criticize state hegemony formal justice and fairness with local values.

\section{LOCAL VALUES AND SOCIETY SYSTEM}

Legal multicultural aims to look local value that stays beside national law. It observes from local and national law. In addition, it will affect the effectiveness of law, so that researcher needs to see the law practicality or unpracticality. Related to the legal effectiveness or enforceability, there were three differences, namely the enforceability of the law in empirical, normative, and evaluative ${ }^{10}$. The effectiveness of law was influenced by three basic components, such as structure, substance, and culture ${ }^{11}$. Structure links to other systems in order to implement the legal process while substance regards the rules and how legal institution must implement it.

Through anthropological obtains very complex of plurality and heterogeneity in Indonesia. Plurality shows that diversity must be mutual respectful, especially for local values. Legal multicultural is postmodernism

\footnotetext{
${ }^{9}$ Bernard L. TANYA, Teori Hukum Strategi Tertip Manusia Lintas Ruang dan Generasi (LEGAL THEORY ACROSS SPACE AND GENERATION) (Surabaya: CV Kita Press 2007).

${ }^{10}$ J. J. H. BRUGGINK, Refleksi tentang Hukum (REFLECTION OF LAw) (Bandung: Citra Aditya Bakti 1996).

${ }^{11}$ Wolfang Friedman, Teori dan Filsafat Hukum, Telaah Kritis atas Teori-teori Hukum (THE ChANGing Structure OF InTERnATIONAL LAW AND AdAPTATION), translated by Mohammad Arifin. (Jakarta: Raja Rgafindo Persada Press 1996).
} 
law that uses the impartiality and objectivity, judges, and other law enforcement agencies, especially in legal and law enforcement bias or political partisanship and ideology.

However, some scholars argue that the term "conflict" can be distinguished from "conflict". First, conflict implies wider than conflict because conflict may include latent and manifest. Manifest conflict called the conflict. While the other persons don't know called latent conflict. Conflict only is felt by the warring parties. Second, conflict refers to conflicts that the institute has or has not been clearly identified. A person can be in conflict with the other people in politics, religions, sociality and economy environment are not accordance with his principles. Like this, one is dealing with the parties that have not been clearly identified. Conversely, a conflict has clearly known and identified his/her opposites.

Third, the term conflict is more often found in the literature of the social sciences and political than in law. Nevertheless the term conflict resolution generally is discovered in anthropological, sociology, and political science. ${ }^{12}$ In contrary, the term conflicts are more often devised and used in legal studies, such as civil conflicts, trade conflicts, family conflicts, producers and consumers conflicts, and state administration conflict. So, conflicts are more often used in legal studies. ${ }^{13}$ Thus, the legal settlements are not always influenced by the boundary and rigid both private law and criminal law as well as the Western legal system. It is also reflected below:

Peace in the system of customs and customary law, we not limited to civil conflicts. Peace is also prevalent in case that are penal of law. Not infrequently criminal acts that can be resolved amicably, in the event of death due to a fight or quarrel, peace, occur through compensation to the families of victims. Compensation is not merely material. ${ }^{14}$

Conflicts can be resolved by way of consensus. At least two competitive theoretical views can explain or answer these essential issues. The first refers to the theoretical view of culture as the dominant factor. People who inherit cultural tradition that emphasizes the importance of harmony and unity of life will be able to receive and use methods of consensus in resolving conflicts. Culture could be formed or influenced by a factors number, including religion. The values of Islam such as the

\footnotetext{
${ }^{12}$ Munir Fuady, Filsafat dan Teori Hukum Postmodern (Philosophy And Postmodern Legal THEORY) (Bandung: PT Citra Aditya Bakti Press 2005).

${ }^{13}$ Sudarto P. HADI, Resolusi Konflik (CONFlik Resolution) (Semarang: Universitas Diponegoro Press 2004).

${ }^{14}$ Bagir Manan, Mediasi Sebagai Alternatif Menyelesaikan Sengketa (Mediation as Resolution Conflict Alternative), 248(3) VARIA PERADILAN 34-44 (2006).
} 
importance of the concept of forgiveness and reconciliation (peace) are a factor that drives normative for the adherents of Islam in order to cover the settlement of conflicts through consensus approach of the parties in deciding the approach side. ${ }^{15}$ However, the concept of reconciliation should not be done if it aims to justify the unlawful or proscribe kosher.

\section{LOCAL VALUE IN AgRARIAN CONFLICT}

Historically, Indonesia viewed as one of the nation very upholds the values of a consensus in solving the problems. Some ethnics found that local values describe consensus in the resolution of issues. For example, Minangkabau people encountered the phrase: "bulek air dek pembuluh, bulek kato dek mufakat" (round water for bamboo, round the word for consensus). This expression implies that something can be resolved by way of consensus of the parties who attended the forum.

Mediation in the resolution of agrarian conflicts, Indonesian Presidential Regulation No. 10/2006 on the National Agrarian Agency, says that the Deputy Assessment and Handling Conflicts and Conflict at the National Agrarian Agency performs functions of an alternative implementation of the settlement issue and conflict over agrarian through forms of mediation, facilitation, and others. The provisions of article 23 imply that, the government is to use mediation as a way for the settlement of agrarian conflicts. Consensus is one way of solving agrarian conflicts.

Presidential Regulation issued have no symptoms apart from the growing popularity of mediation within the terms of law and policy makers as well as laws and regulations in Indonesia. There is no law in used details of mediation in the context of defense Conflict. These conditions exist only in the Technical Guidelines issued by the National Defense Agency No. 05 /Technical Guidance/ D.V/2007 on the Implementation Mechanism of Mediation. Technical guidelines of the preamble, it known that one of the laws that formed the basis is Act No. 30 of 1999 on Arbitration and Alternative Conflict Resolution. This act expressly provides that the use of arbitration and alternative conflict resolution is voluntary, therefore, used of mediation to conflict the defense is also voluntary.

Conflict resolution or often known as alternative conflict resolution (ADR) in Indonesia is considered interesting and significant if it is associated with the views of the political elite and the thinking of most legal

\footnotetext{
${ }^{15}$ Syahrizal AbBas, Mediasi dalam Perspektif Hukum Syariah, Hukum Adat, dan Hukum Nasional, CIDA (Mediation in Shari'a Perspective, Customary Law, and National Law, CIDA) (Banda Aceh: Religion Department of Republic of Indonesia 2009).
} 
experts who want to actualize the various institutions or values that live in the community customary law to address the social problems. Deliberations to reach a conclusion about the conflict resolution process and decision making are considered to be rooted in customary law communities, in addition to meetings there are other ways commonly used by the public in resolving problems or conflicts.

Local values are very attentive to any problems that confronted him in particular with belief that every problem is not same as like the other questions though similar. ${ }^{16}$ Further it is explained that every matter should receive special treatment in accordance with individuality. The arrangement is not made a priori, but always situational and individual, so that the conflict settlement gains complete and comprehensive solution that can address all aspects of existing and which may exist in the future. In this connection, it should be noted the application of the principle of work: harmonious, inappropriate, and barrel.

The role of local values deemed effectively, especially in the indigenous communities that still maintain the value of their local wisdom. People would not compartmentalized in the bulkhead formalistic confining them, so that they were far from the name of substantive justice, since the law has a character of a formal, then its image as an institution that maintains the status quo-is quite large, which appears in the issue of legality. As such, about the legality or the rule of law becomes a big issues of its own in the positive law, and this will hamper the dynamics local values communities. It is not rare clash between legal certainty and benefit of law for the people.

Meaning of peace is the totality of mission to spread the grace and achieve peace for the universe, which is the purpose of life in the archipelago. Agrarian conflict model is based on local values local moral as following considerations:

1) To satisfy the parties, and neither is won and lost.

2) To deliver the peace of heart and inner satisfaction.

3) To strengthen the ties of the parties in conflict.

Deliberation is as one of the basic principles animating a civilized society. It is related to public interest that can be found a way out as well as possible after all the parties put forward the views and thoughts that must be heard for making a decision, so as to reflect the objective consideration and prudent for the existence of mutual interest to the community. Consultative

\footnotetext{
${ }^{16}$ I. Gusti Sulendra, Lahmuddin Zuhri \& Juanda, Building Character Education Based on Krik Salamat, 7 (2) US-CHINA EDUCATION REviEW B 110-113 (2017), http://davidpublisher.com/index.php/Home/Article/index?id=31177.html.
} 
meeting may be terminated by unanimity or agreement (consensus). This is contrast to the liberal democracy that is adhered to the majority vote which is ended with the defeat for a party and a victory for the other sides.

The principle of consultation to involve or invite all interested parties to participate in public life, so that loyalty and obedience of the people against what was agreed together will be maintained as well as togetherness, as the agreement was the fruit of their thoughts and opinions in shades of kinship and mutual glorify. This means that if those are who abuse tantamount break the brotherhood and kinship, and no respect for others. ${ }^{17}$ Thus there arose a shame if it did not accomplish them what had become a common consensus earlier.

\section{CONCLUSION}

The mediation model needs to be disclosed and aims to be preventive. While the state has not function social institutions and culture as conflict resolution. Instead it chooses a model litigation consequences emergence of hostility because there are elements win-lose- are packed to seek justice.

Agrarian conflict model is referring to the all-around and intact between people, nature, and God. Completion of agrarian conflict-based local values is considerations. Firstly, to satisfy the parties, and neither is won nor lost; Second, to usher in peace of heart and inner satisfaction; Third, to strengthen the ties of the parties to the conflict; Fourth, the agreement is the fruit of their thoughts and opinions together in shades of kinship and mutual glorify.

\footnotetext{
${ }^{17}$ Syaifuddin Iskandar \& Lahmuddin Zuhri, Posisi Nilai Lokal dalam Peraturan Daerah (Local Value in Regency Regulation), 18(2) JURNAL UNSA PROGRESS 78-83 (2015).
} 